\title{
The anti-tumour properties and biodistribution (as determined by the radiolabeled equivalent) of Au-compounds intended as potential chemotherapeutics
}

\author{
M.J. Nell ${ }^{a}$, J.M. Wagener ${ }^{b}$, J.R. Zeevaart ${ }^{c}$, E. Kilian ${ }^{\text {d }}$, M.A. Mamo ${ }^{\mathrm{e}}$, M. Layh ${ }^{\mathrm{e}}$, M. Coyanis ${ }^{\mathrm{f}}$ and \\ C.E.J. van Rensburga
}

${ }^{a}$ Department of Pharmacology, University of Pretoria, P.O. Box 2034, Pretoria 0001, South Africa

${ }^{\mathrm{b}}$ Radiochemistry, NECSA (South African Nuclear Energy Corporation Ltd.), P.O. Box 582, Pretoria 0001, South Africa

${ }^{\mathrm{c}}$ CARST, North West University, Mafikeng Campus, P. Bag X2046, Mmabatho 2735, South Africa

${ }^{\mathrm{d}}$ Department of Pharmacology, Onderstepoort, University of Pretoria, P.O. Box 2034, Pretoria 0001, South Africa

${ }^{\mathrm{e}}$ Molecular Sciences Institute, School of Chemistry, University of the Witwatersrand, Private Bag 3, Wits, 2050 Johannesburg, South Africa

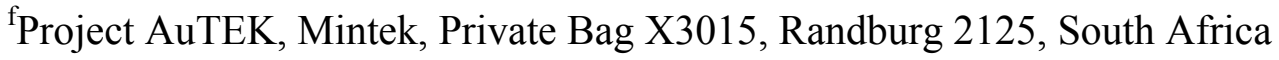

\begin{abstract}
The anti-tumour activity of the $\mathrm{Au}(\mathrm{I})$ phosphine complex [Au(dppe $\left.\mathrm{A}_{2}\right] \mathrm{Cl}$ was first discovered in the mid 1980s although promising results were obtained it did not pass clinical studies because of its toxicity to organs such as the liver and heart. The aim of this study was to determine whether the two novel gold compounds (MM5 and MM6), selected for this study, have higher selectivity for cancer cells with less toxicity towards normal cells than $\left[\mathrm{Au}(\mathrm{dppe})_{2}\right] \mathrm{Cl}$, and also to determine whether they have improved bio distribution compared to [Au(dppe $\left.)_{2}\right] \mathrm{Cl}$. The Au-compounds as potential chemotherapeutic drugs were evaluated by using radioactive tracers in the in vitro and in vivo studies.

Results obtained from these experiments showed that the uptake of these experimental compounds was dependent on their octanol/water partition coefficient. However; the inhibition of cell growth did not correlate with the uptake of these compounds by the cells that were tested.

In terms of the total uptake it was found that the compounds that were less lipophilic (MM5, MM6) were taken up less efficiently in cells than those that are more lipophilic. Therefore hydrophilic
\end{abstract}


drugs are expected to have a limited biodistribution compared to lipophilic drugs. This might imply a more selective tumour uptake.

Keywords: Au-compounds; Anti-tumour activity; Radioactive tracers; Biodistribution

\section{Introduction}

Gold derivatives are well known for their clinical use in the treatment of rheumatoid arthritis, but they have also shown promise as anti-tumour agents. Promising results were obtained with $\left[\mathrm{Au}(\mathrm{dppe})_{2}\right] \mathrm{Cl}$ as an anti-cancer agent, but in pre-clinical toxicity studies with Beagle dogs, $\left[\mathrm{Au}(\mathrm{dppe})_{2}\right] \mathrm{Cl}$, was shown to produce cardiac, hepatic and vascular toxicities. In vitro, $\left[\mathrm{Au}(\mathrm{dppe})_{2}\right] \mathrm{Cl}$ was also very cytotoxic to isolated dog and rat hepatocytes (Hoke et al., 1988; Smith et al., 1989). Pre-clinical development of $\left[\mathrm{Au}(\mathrm{dppe})_{2}\right] \mathrm{Cl}$ was abandoned because of the severe hepatotoxicity in dogs. The hepatotoxicity was attributed to alterations in mitochondrial function. $\left[\mathrm{Au}(\mathrm{dppe})_{2}\right] \mathrm{Cl}$ is very lipophilic and consequently targets the mitochondria in all cells. (BernersPrice et al., 1999).

The lipophylic-cationic nature of the complex seems important and early studies provided evidence for an anti-mitochondrial mode of action (Hoke et al., 1991). In vitro studies of $\left[\mathrm{Au}(\mathrm{dppe})_{2}\right] \mathrm{Cl}$ showed that the compound is cytotoxic to tumour cell lines and is only minimally inhibited by serum. It produces DNA protein cross-links and DNA strand breaks in cells; it also inhibits macromolecular synthesis with a preferential inhibitory effect on protein synthesis relative to DNA and RNA synthesis (Berners-Price et al., 1986).

It is therefore important to investigate treatment strategies aimed at novel cellular targets that are sufficiently different between normal cells and cancer cells to provide a basis for selective tumour killing (Modica-Napolitano and Aprille, 2001). As a result there has been considerable interest in targeting mitochondrial cell death pathways in the development of new chemotherapeutic agents (Debatin et al., 2002).

$\left[\mathrm{Au}(\mathrm{dppe})_{2}\right] \mathrm{Cl}$ is known to have an effect on the mitochondrial membrane potential of cells. MM5 and MM6 were compared to $\left[\mathrm{Au}(\mathrm{dppe})_{2}\right] \mathrm{Cl}$ for effects on mitochondrial membrane potential. $\left[\mathrm{Au}(\mathrm{dppe})_{2}\right] \mathrm{Cl}, \mathrm{MM} 5$ and MM6 depolarized the mitochondrial membranes of PHA stimulated lymphocytes significantly, while only $\left[\mathrm{Au}(\mathrm{dppe})_{2}\right] \mathrm{Cl}$ depolarized the mitochondrial membranes of the Jurkat cells significantly, indicating that a different mechanism of action might be operational. The choice for the design or selection of potentially therapeutic lipophilic cations has been based almost solely on physical properties (i.e., lipid solubility and delocalization of positive charge) and 
the preliminary screening for the selective cytotoxicity of these compounds is very important (Modica-Napolitano and Aprille, 2001).

In this study, the structure of $\left[\mathrm{Au}(\mathrm{dppe})_{2}\right] \mathrm{Cl}$ has been modified by the University of the Witwatersrand. Three novel radiolabeled gold complexes, [Au(dppe $\left.)_{2}\right] \mathrm{Cl}$, MM5 and MM6 were prepared from the appropriate labeled precursor compounds, $\mathrm{HAuCl}_{4} \cdot 4 \mathrm{H}_{2} \mathrm{O}$ and $[\mathrm{AuCl}(\mathrm{THT})]$. These complexes have successfully been applied in vitro (Tsuruo et al., 1982) to study the cellular uptake and ultimately gain an insight into the mechanism by which these complexes exert their cytotoxic effect. The benefit of the radioactive metal as tracer was used for the in vivo animal studies to evaluate the biodistribution in rodents. Although $\left[\mathrm{Au}(\mathrm{dppe})_{2}\right] \mathrm{Cl}$ was shown to be toxic, it is still an important reference compound and will serve as a control against the two novel compounds tested.

\section{Materials and methods}

\subsection{Experimental drugs}

The molecular structures of the compounds MM5 and MM6 can be seen in Fig. 1. [Au(dppe $\left.)_{2}\right] \mathrm{Cl}$ was included for comparison. $10 \mathrm{mM}$ stock solutions of the experimental compounds in DMSO were prepared (DMSO concentration $\leqslant 0.1 \%$ ). Further dilutions were done in the appropriate tissue culture medium which was supplemented with $10 \%$ heat inactivated foetal calf serum (FCS) just before use.
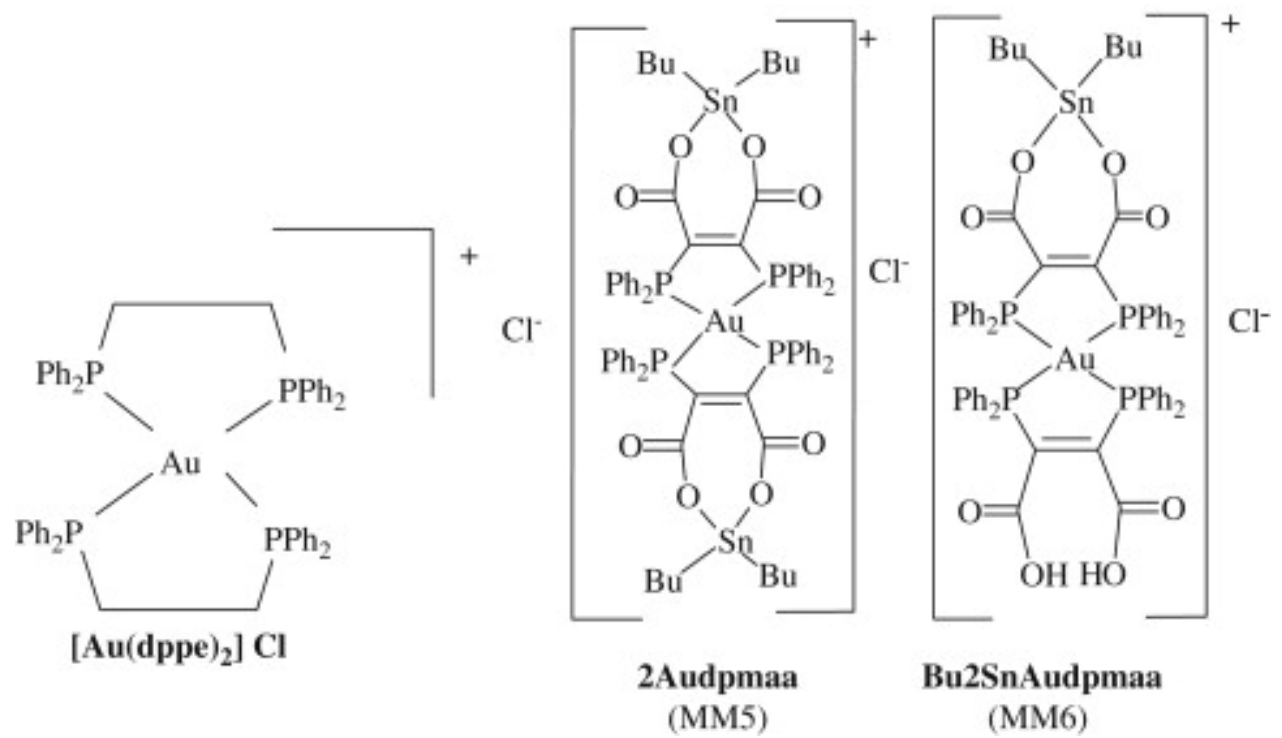

Fig. 1. Structures of [Au(dppe $\left.)_{2}\right] C l, M M 5$ and MM6. 


\subsection{Cell lines and cell cultures}

The following cancer cell lines were used:

(i) human cervical carcinoma (HeLa, ATCC no CCL 2)-adherent epithelial cells maintained in Eagles minimum essential medium containing $2 \mathrm{mM}$ l-glutamine, $0.1 \mathrm{mM}$ non-essential amino acids, $1.0 \mathrm{mM}$ sodium pyruvate and 5\% bovine FCS.

(ii) colon cancer cell line (CoLo 320 DM, ATCC no CCL-220) and Jurkat cells (human T-cell line) (NRBM no 0062) that grow loosely attached in suspension and are rounded and refractile. They are maintained in RPMI 1640 medium with $10 \%$ bovine FCS.

(iii) breast carcinoma (MCF 7, ATCC no HTB 22) — adherent epithelial cells maintained in Dulbecco's minimum essential medium containing $2 \mathrm{mM}$ l-glutamine, $0.1 \mathrm{mM}$ non-essential amino acids, $1.0 \mathrm{mM}$ sodium pyruvate and $5 \%$ bovine FCS.

(iv) prostate cancer cell line (Du 145, ATCC no HTB-81), human ovarian carcinoma, (A2780, ECACC no 93112519), and a variant thereof, resistant to cisplatin (A2780 Cis, ECACC no 93112517) — adherent epithelial cells maintained in RPMI 1640 medium with 10\% bovine fetal calf serum. In the case of A2780 Cis, $0.3 \mu \mathrm{g} / \mathrm{ml}$ cisplatin was added to the growth medium to maintain cisplatin resistance. Cisplatin in growth media was removed 24 hours prior to experiments.

(v) mouse melanoma (B16, ECACC no 92101203) — adherent epithelial cells maintained in RPMI 1640 medium supplemented with $10 \%$ bovine FCS.

To determine the tumour specificity for each experimental compound the following non-cancerous and primary cell cultures were used:

(i) primary chicken embryo fibroblasts adherent cells that are isolated from chicken embryos (Freshney, 2000), maintained in RPMI 1640 medium with 10\% bovine fetal calf serum

(ii) primary human lymphocytes were isolated as described by Anderson et al., 1993, from heparinized peripheral blood and maintained in RPMI 1640 medium with 10\% bovine FCS. (iii) primary porcine hepatocytes were provided by the Bio Liver Research Unit, Dept of Internal Medicine, University of Pretoria. These cells were prepared according to standard procedures as described by Frühauf et al. (2004) and Nieuwoudt et al. (2005). Primary porcine hepatocytes are adherent epithelial cells and maintained in Eagles minimum essential medium containing $2 \mathrm{mM} 1-$ glutamine, $0.1 \mathrm{mM}$ non-essential amino acids, $1.0 \mathrm{mM}$ sodium pyruvate and $10 \%$ bovine FCS. The bovine FCS that was used to supplement the growth media was heat inactivated at $56{ }^{\circ} \mathrm{C}$ for 30 minutes. All the cultures were cultivated in the presence of $1 \%$ penicillin and streptomycin and were maintained at $37{ }^{\circ} \mathrm{C}$ with $5 \% \mathrm{CO}_{2}$. Cultures were sub-cultured as needed.

\subsection{Cytotoxicity assay}

Cytotoxicity assays are performed to establish the sensitivity of cancer cell lines and normal cell cultures to the experimental compounds. A known concentration of cells is exposed to different concentrations of the experimental drug in a 96 well tissue culture plate and incubated for a period of time. Drug free solvent controls were included. Cancer cells were seeded at $4-5 \times 10^{2} /$ well and were incubated for 7 days. Fibroblasts and hepatocytes were seeded at $2 \times 10^{4} /$ well and also incubated for 7 days. Lymphocytes were seeded at $2 \times 10^{5} /$ well and incubated for 3 days. The viability of cells was determined with the MTT method (Hoke et al., 1988). $20 \mu$ of MTT [3-(4,5-dimethylthiazol-2-yl)-2, 5-diphenyl tetrazolium bromide] (Sigma Diagnostics Inc.) was added to each well. MTT is a pale 
yellow substance that is metabolized to dark blue formazan crystals by metabolically active cells. The same method will be used for both cancer cells and normal cell lines.

\subsection{Lipophilicity assay}

Partition coefficients (PC) between water and octanol were determined using standard methods (Shake flask method). Concentrations in each phase were calculated from UV-vis absorption data using extinction coefficients determined in water-saturated octanol and in octanol-saturated water (Bowen, 1999).

Results are expressed as the mean log values of the final octanol/water partition coefficient value.

\subsection{Determination of mitochondrial membrane potential}

A standard flow cytometric method with the mitochondrial membrane stain, JC-1 was used for this study as described by Cossarizza et al., 1993.

By using JC-1 it is possible to detect single cell variations in mitochondrial membrane potential. JC1 is able to enter selectively into mitochondria and this is dependant on mitochondrial membrane potential. The colour of the dye changes reversibly from green to red as the mitochondrial membrane becomes more polarized (Cossarizza et al., 1993).

The selected experimental compounds (MM5 and MM6) were tested on Jurkat cells and normal PHA stimulated lymphocytes for effects on mitochondrial membrane potential together with $\left[\mathrm{Au}(\mathrm{dppe})_{2}\right] \mathrm{Cl}$.

Concentrations equal to the $\mathrm{IC}_{50}$ value and double the $\mathrm{IC}_{50}$ value of the experimental compounds were used. An untreated control and a positive control were included. Valinomycin was used as the positive control at concentrations of 0.1 and $10 \mu \mathrm{M}$ (Cossarizza et al., 1993; Caruso et al., 2007).

\subsection{Apoptosis}

A standard flow cytometer method with propidium iodide (PI) and Annexin V-FITC staining was used as described by Michie et al., 2003.

This method measures the decline of viable cells and the appearance of early apoptotic and late apoptotic/necrotic cells in one assay. The method is based upon Annexin V-FITC binding to tag early apoptotic cells and PI staining to identify late apoptotic/necrotic cells (Michie et al., 2003; Tuschl and Schwab, 2004).

$\left[\mathrm{Au}(\mathrm{dppe})_{2}\right] \mathrm{Cl}, \mathrm{MM} 5$ and MM6 were tested to determine whether they induce apoptosis in Jurkat cells. Concentrations equal to the $\mathrm{IC}_{50}$ value and double the $\mathrm{IC}_{50}$ value of the experimental compounds were used. 


\subsection{Preparation of radiolabeled Au-compounds}

Natural $\mathrm{Au}(\mathrm{s})$ was irradiated for $10 \mathrm{~min}$ in the Necsa Safari-1 nuclear reactor, at a thermal flux of $8.0 \times 10^{13} \mathrm{n} \mathrm{cm}^{-2} \mathrm{~s}^{-1}$ in the hydraulic position for the synthesis of the ${ }^{198} \mathrm{Au}$ radiolabeled compounds, $\left[\mathrm{Au}(\mathrm{dppe})_{2}\right] \mathrm{Cl}, \mathrm{MM} 5$ and MM6. The synthesis of the compounds was done according to previously published procedures (Berners-Price and Sadler, 1986; Mahepal et al., 2008).

\subsection{Synthesis}

(1a) $\mathrm{HAuCl}_{4} \cdot 4 \mathrm{H}_{2} \mathrm{O}: 0.213 \mathrm{mmol}$ activated $\mathrm{Au}(41.9 \mathrm{mg})$ and $0.368 \mathrm{mmol}$ cold $\mathrm{Au}(30.5 \mathrm{mg})$ was dissolved in $680 \mu \mathrm{HCl} / \mathrm{HNO}_{3}$ (ratio 3:1; bubbled with Ar) at $45^{\circ} \mathrm{C}$. The yellow residue was washed with $650 \mu \mathrm{HCl}$ and $650 \mu 1 \mathrm{H}_{2} \mathrm{O}$. The product was dried at $50{ }^{\circ} \mathrm{C}$ after each wash step.

(1b) ClAuTHT: The product in (1a) was dissolved in $900 \mu \mathrm{EtOH} / \mathrm{H}_{2} \mathrm{O}(5: 1)$, filtered through a Millex GP $0.22 \mu \mathrm{m}$ filter, rinsed three times with the $\mathrm{EtOH} / \mathrm{H}_{2} \mathrm{O}$-solution and evaporated under Ar to $\pm 1000 \mu \mathrm{l}$. An excess of THT $(600 \mu \mathrm{l})$ was added and the solution was stirred for $15 \mathrm{~min}$. The solution was extracted. The white precipitate was washed twice with $500 \mu \mathrm{EtOH}$ and dried for $60 \mathrm{~min}$. The product was dissolved in the minimum volume chloroform and divided in three vials for $\mathrm{ClAu}(\mathrm{dppe})_{2}$, (MM5) and (MM6).

(2a) ClAu(dppe) $2: 2.93 \mu \mathrm{l}$ 1(b) (=3.6 mg; $0.0111 \mathrm{mmol})$ was evaporated $(10 \mathrm{~min}) .1 .0 \mathrm{ml} \mathrm{THF}$ (bubbled with Ar) was added to $0.0222 \mathrm{mmol}$ dppe $(8.84 \mathrm{mg}$ ) in a separate vial (under Ar). This solution was added to the dried $\mathrm{AuTHTCl}_{2}$ (under Ar) and stirred for $15 \mathrm{~min}$. The white precipitate was dried in vaco for $30 \mathrm{~min}$.

(2b) $\mathrm{Au}\left(\right.$ dpmaa) ${ }_{2} \mathrm{Cl} .2 \mathrm{SnBu}_{2}$ (MM5): $179 \mu \mathrm{l}$ (b) (=2.2 mg, $\left.0.007 \mathrm{mmol}\right)$ was evaporated (10 min). $0.5 \mathrm{ml}$ THF (bubbled with Ar) was added to $0.014 \mathrm{mmol} \mathrm{Bu}_{2} \mathrm{Sn}(\mathrm{O}, \mathrm{O}-\mathrm{dpmaa})(9.83 \mathrm{mg}$ ) in a separate vial (under Ar). This solution was added to the dried $\mathrm{AuTHTCl}_{2}$ (under Ar) and stirred for $15 \mathrm{~min}$. A deep yellow-orange precipitate formed and was dried in vaco for $30 \mathrm{~min}$.

(2c) $\mathrm{Au}(\text { dpmaa })_{2} \mathrm{Cl} . \mathrm{SnBu}_{2}$ (MM6): $131 \mu \mathrm{l} 1$ (b) (=1.61 mg; $\left.0.005 \mathrm{mmol}\right)$ was evaporated (10 min). $0.5 \mathrm{ml}$ THF (bubbled with Ar) was added to $0.005 \mathrm{mmol} \mathrm{Bu}_{2} \mathrm{Sn}(\mathrm{O}, \mathrm{O}-\mathrm{dpmaa})(3.6 \mathrm{mg})$ and $0.005 \mathrm{mmol}$ dpmaa $(3.13 \mathrm{mg}$ ) in a separate vial (under Ar). This solution is added to the dried $\mathrm{AuTHTCl}_{2}$ (under Ar) and stirred for $15 \mathrm{~min}$. The light cream yellow precipitate was dried in vaco for $30 \mathrm{~min}$.

\subsection{Formulation for in vivo studies}

(a) $\left[\mathrm{Au}(\text { dppe })_{2}\right] \mathrm{Cl}: 1200 \mu \mathrm{EtOH}$ and $7200 \mu \mathrm{H} \mathrm{H} \mathrm{H}_{2} \mathrm{O}$ was added to $11.43 \mathrm{mg}$ [Au(dppe $\left.)_{2}\right] \mathrm{Cl}$. A $3000 \mu \mathrm{l}$ fraction was filtered (Millex GP $0.22 \mu \mathrm{m}$ ). An injection volume of $500 \mu \mathrm{l}$ was used $\left(5.0 \times 10^{-2} \mu \mathrm{Ci} / \mu \mathrm{l}\right)$. 
(b) MM5: $400 \mu \mathrm{D}$ DMSO, $1600 \mu \mathrm{l} \mathrm{EtOH}$ and $7200 \mu 1 \mathrm{H}_{2} \mathrm{O}$ were added to $11.43 \mathrm{mg}$ MM5. The filtered $4000 \mu \mathrm{l}$ fraction had an activity of $11 \mu \mathrm{Ci}$. An injection volume of $500 \mu 1$ was used $\left(2.75 \times 10^{-3} \mu \mathrm{Ci} / \mu \mathrm{l}\right)$.

c) MM6: $280 \mu \mathrm{DMSO}$ was added to $7.16 \mathrm{mg} \mathrm{MM6.} 700 \mu \mathrm{EtOH}$ and $2400 \mu 1 \mathrm{H}_{2} \mathrm{O}$ was added to $100 \mu \mathrm{l}$ of the MM6 suspension. The filtered solution had an activity of $13 \mu \mathrm{Ci}$. An injection volume of $450 \mu \mathrm{l}$ was used $\left(4.06 \times 10^{-3} \mu \mathrm{Ci} / \mu \mathrm{l}\right)$.

\subsection{In vitro drug uptake of radiolabeled Au-compounds}

A standard method to measure drug uptake in cancer cells was used. Cellular uptake of the drugs was measured in RPMI supplemented with 10\% bovine FCS as described by Tsuruo et al., 1982). A2780 and A2780 cis cell cultures were used. Experiments were carried out in a registered radioactive laboratory and applicable safety measures were adhered to.

\subsection{In vivo rodent studies}

All studies were performed after approval by the Ethics Committee of the University of Pretoria, according to the guidelines of the National Code for Animal Use in Research, Education, Diagnosis and Testing of Drugs and Related Substances in South Africa. Six adult male Sprague Dawley rats obtained from the UBPRC at Onderstepoort were injected each with an extremely low, non-toxic dosage of the radiolabeled compound $\left({ }^{198} \mathrm{Au}\right.$ labeled $\left[\mathrm{Au}(\mathrm{dppe})_{2}\right] \mathrm{Cl}$, MM5 and MM6). The tests were carried out over three consecutive days, each day with a new compound. A total of 18 rats were used. On the day of the experiment, the animals were anaesthetised by an intra peritoneal (ip) injection of a $6 \%$ sodium pentobarbitone solution at a dose of $1 \mathrm{ml} / \mathrm{kg}$. A $24 \mathrm{G}$ jelco was inserted into the tail vein of the animals to administer the radiolabeled compounds. Two animals per group were scanned in parallel with an Elscint Gamma Camera at the Diagnostic Imaging unit at Onderstepoort in order to obtain the radionuclide imaging. Two minute static studies were performed every half an hour up to 6 hours. Isoflurane was used to immobilize the animals for the 2 min static studies. The animals were sacrificed using an Isoflurane overdose after a six-hour period. The organs were separated and counted in a well type counter at Necsa. From the organ counts as well as the reference activity in a syringe the $\% \mathrm{ID} / \mathrm{g}$ (injected dose/gram) was calculated.

\section{Results and discussion}

The aim of this study was to determine whether the two novel gold compounds (MM5 and MM6), selected for this study, have higher selectivity for cancer cells with less toxicity towards normal cells than $\left[\mathrm{Au}(\mathrm{dppe})_{2}\right] \mathrm{Cl}$, and also to determine whether they have improved biodistribution compared to 
$\left[\mathrm{Au}(\mathrm{dppe})_{2}\right] \mathrm{Cl}$. The aim was also to compare the anti-mitochondrial characteristics of $\left[\mathrm{Au}(\mathrm{dppe})_{2}\right] \mathrm{Cl}$ with the novel compounds to see whether they have the same mechanism of action.

\subsection{Lipophilicity assay}

The mean log octanol/water PC values are shown in Table 1. [Au(dppe $\left.)_{2}\right] \mathrm{Cl}$ has a mean log octanol/ water PC of 1.081 that indicates that it is a lipophilic compound. MM5 and MM6 are strong hydrophilic. Berners-Price et al. (1999) established a significant correlation between drug uptake and the octanol/water partition coefficient of a compound. $\left[\mathrm{Au}(\mathrm{dppe})_{2}\right] \mathrm{Cl}$ had strong lipophilic characteristics and cells had a much higher uptake of this compound compared to MM5 and MM6 which were strong hydrophilic. ${ }^{198} \mathrm{Au}$ labeled $\left[\mathrm{Au}(\mathrm{dppe})_{2}\right] \mathrm{Cl}$, MM5 and MM6 were used to determine drug uptake.

Table 1. The mean octanol/water partition coefficient values $\pm S E M$ and the mean log octanol/water partition values $\pm S E M$ of $\left[\mathrm{Au}(\mathrm{dppe})_{2}\right] \mathrm{Cl}, \mathrm{MM} 5$ and MM6.

Octanol/water partition coefficient and mean log octanol/water partition coefficient \pm SEM

\begin{tabular}{|l|l|l|}
\hline $\begin{array}{l}\text { Experimental } \\
\text { compounds }\end{array}$ & $\begin{array}{l}\text { Mean octanol/water partition } \\
\text { coefficient } \pm \text { SEM }\end{array}$ & $\begin{array}{l}\text { Mean log octanol/water partition } \\
\text { coefficient } \pm \text { SEM }\end{array}$ \\
\hline$\left[\mathrm{Au}(\mathrm{dppe})_{2}\right] \mathrm{Cl}$ & $13.718 \pm 0.841$ & $1.136 \pm 0.027$ \\
\hline $\mathrm{MM} 5$ & $0.169 \pm 0.143$ & $-1.045 \pm 0.540$ \\
\hline $\mathrm{MM} 6$ & $0.043 \pm 0.027$ & $-1.209 \pm 0.255$ \\
\hline
\end{tabular}

Each value represents the mean of five independent experiments.

\subsection{Activity of the novel gold compounds and standards against cancer cell lines and normal} cultures

The two novel compounds together with $\left[\mathrm{Au}(\mathrm{dppe})_{2}\right] \mathrm{Cl}$ were tested on various cell cultures (malignant and non-malignant) to determine tumour selectivity and specificity.

$\mathrm{IC}_{50}$ values obtained for the experimental compounds on cancer cell lines are shown in Table 2 . The cisplatin sensitive cell line (A2780) was the most sensitive to the experimental compounds, while A2780 (cis) and the Jurkat cells were the least affected. 


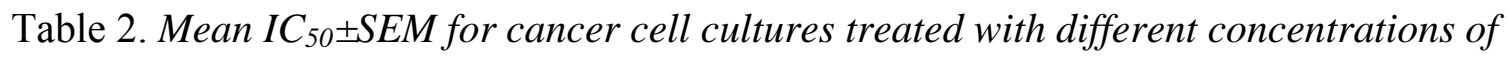
[Au(dppe)2]Cl, MM5 and MM6 for 7 days.

Calculated $\mathrm{IC}_{50}{ }^{\mathrm{a}}(\boldsymbol{\mu M})$ for three different drugs on cancer cell lines ${ }^{\mathrm{b}}$

\begin{tabular}{|c|c|c|c|c|c|c|c|c|}
\hline Drug & A 2780 & $\begin{array}{l}\text { A } 2780 \\
\text { cis }\end{array}$ & B16 & CoLo & Du 145 & HeLa & Jurkat & MCF 7 \\
\hline $\begin{array}{l}{[\mathrm{Au}(\mathrm{dppe})} \\
\left.{ }_{2}\right] \mathrm{Cl}\end{array}$ & $\begin{array}{l}0.0084 \pm 0 \\
001\end{array}$ & $\begin{array}{l}0.437 \pm 0 \\
066\end{array}$ & $\begin{array}{l}0.051 \pm 0 . \\
004\end{array}$ & $\begin{array}{l}0.291 \pm 0 . \\
06\end{array}$ & $\begin{array}{l}0.009 \pm 0.0 \\
02\end{array}$ & $\begin{array}{l}0.778 \pm 0 . \\
07\end{array}$ & $\begin{array}{l}0.157 \pm 0 . \\
023\end{array}$ & $\begin{array}{l}0.568 \pm 0 \\
065\end{array}$ \\
\hline MM5 & $\begin{array}{l}0.041 \pm 0.0 \\
08\end{array}$ & $\begin{array}{l}0.295 \pm 0 \\
025\end{array}$ & $\begin{array}{l}0.576 \pm 0 . \\
004\end{array}$ & $\begin{array}{l}0.121 \pm 0 . \\
011\end{array}$ & $\begin{array}{l}0.056 \pm 0.0 \\
09\end{array}$ & $\begin{array}{l}0.039 \pm 0 . \\
007\end{array}$ & $\begin{array}{l}0.261 \pm 0 \\
017\end{array}$ & $\begin{array}{l}0.145 \pm 0 \\
019\end{array}$ \\
\hline MM6 & $\begin{array}{l}0.040 \pm 0.0 \\
09\end{array}$ & $\begin{array}{l}0.347 \pm 0 \\
037\end{array}$ & $\begin{array}{l}0.514 \pm 0 . \\
033\end{array}$ & $\begin{array}{l}0.112 \pm 0 \\
013\end{array}$ & $\begin{array}{l}0.0631 \pm 0 . \\
007\end{array}$ & $\begin{array}{l}0.105 \pm 0 . \\
018\end{array}$ & $\begin{array}{l}0.369 \pm 0 . \\
044\end{array}$ & $\begin{array}{l}0.150 \pm 0 \\
027\end{array}$ \\
\hline
\end{tabular}

${ }^{a}$ Average of seven independent experiments.

${ }^{\mathrm{b}} \mathrm{IC}_{50}=$ the concentration $(\mu \mathrm{M})$ of the experimental compound inducing a $50 \%$ decrease in cell growth.

The activity of the novel gold compounds and $\left[\mathrm{Au}(\mathrm{dppe})_{2}\right] \mathrm{Cl}$ against normal cells are shown in Table

3. The normal cells were less sensitive to the experimental compounds than the cancer cells.

Table 3. Mean IC ${ }_{50} \pm S E M$ for normal cell cultures treated with different concentrations of [Au(dppe)2]Cl, MM5 and MM6 for 3 or 7 days.

Calculated $\mathrm{IC}_{50}{ }^{\mathrm{a}}(\boldsymbol{\mu M})$ for 3 different drugs on normal cell cultures ${ }^{\mathrm{b}}$

\begin{tabular}{|c|c|c|c|c|}
\hline Drug & $\begin{array}{l}\text { Chicken embryo } \\
\text { fibroblasts }\end{array}$ & $\begin{array}{l}\text { Porcine } \\
\text { hepatocytes }\end{array}$ & $\begin{array}{l}\text { Lymphocytes (PHA } \\
\text { stimulated) }\end{array}$ & $\begin{array}{l}\text { Lymphocytes } \\
\text { (resting) }\end{array}$ \\
\hline$\left[\mathrm{Au}(\mathrm{dppe})_{2}\right] \mathrm{Cl}$ & $0.226 \pm 0.059$ & $0.560 \pm 0.100$ & $0.254 \pm 0.076$ & $1.095 \pm 0.234$ \\
\hline MM5 & $0.787 \pm 0.083$ & $0.659 \pm 0.140$ & $0.340 \pm 0.047$ & $0.268 \pm 0.032$ \\
\hline MM6 & $0.804 \pm 0.094$ & $0.615 \pm 0.140$ & $0.397 \pm 0.038$ & $0.354 \pm 0.043$ \\
\hline
\end{tabular}

${ }^{\text {a }}$ Average of 7 independent experiments.

${ }^{\mathrm{b}} \mathrm{IC}_{50}=$ the concentration $(\mu \mathrm{M})$ of the experimental compound inducing a $50 \%$ decrease in cell growth. 
Tumour specificity results are shown in Table 4. Tumour specificity is calculated as the average of the $\mathrm{IC}_{50}$ values for primary cultures divided by the average of the $\mathrm{IC}_{50}$ values for the cancer cells.

Table 4. Tumour specificity of [Au(dppe $\left.)_{2}\right] C l, M M 5$ and MM6 was calculated by dividing the mean $I C_{50}$ values of primary cultures by the mean $I_{50}$ values of the cancer cells. MCF $12 \mathrm{~A}$ results were not included in this calculation.

Calculated tumour specificity of three drugs tested on cancer and normal cell cultures

\begin{tabular}{|l|l|}
\hline$\left[\mathrm{Au}(\text { dppe })_{2}\right] \mathrm{Cl}$ & 1.857 \\
\hline MM5 & 2.678 \\
\hline MM6 & 2.553 \\
\hline
\end{tabular}

Results obtained in this study have indicated that $\left[\mathrm{Au}(\mathrm{dppe})_{2}\right] \mathrm{Cl}$ is a strong lipophilic compound. MM5 and MM6 on the other hand were strong hydrophilic compounds, and exhibited more selectivity towards the tumour cells and were consequently less toxic to the normal cells. MM5 and MM6 were \pm 2.5 times more selective towards cancer cells than normal cells.

These experiments indicated that very little MM5 and MM6 were taken up by both the cell lines tested. It is interesting to note that these compounds had very low $\mathrm{IC}_{50}$ values which indicate strong inhibition of growth. This suggests that growth inhibition is not related to drug uptake in these compounds. Drug uptake was dependant on the octanol/water partition coefficient.

\subsection{Mitochondrial membrane potential}

$\left[\mathrm{Au}(\mathrm{dppe})_{2}\right] \mathrm{Cl}$ depolarized the mitochondrial membranes of both Jurkat cells and PHA stimulated human lymphocytes very significantly. The novel compounds depolarized the mitochondrial membranes of Jurkat cells but to a lesser extent than $\left[\mathrm{Au}(\mathrm{dppe})_{2}\right] \mathrm{Cl}$.

The effects of the experimental compounds on the mitochondrial membrane potential of PHA stimulated normal human lymphocytes and Jurkat cells are shown in Table 5 and Table 6 , respectively. $\left[\mathrm{Au}(\mathrm{dppe})_{2}\right] \mathrm{Cl}$ depolarized the mitochondrial membranes significantly at a concentration of 0.254 and $0.508 \mu \mathrm{M}$ in normal PHA stimulated lymphocytes and 0.157 and $0.314 \mu \mathrm{M}$ with the Jurkat cells. Results in Table 5 and Table 6 represent the ratio between green (FL1) and orange (FL2) fluorescence. MM5 and MM6 had a more pronounced effect on the mitochondrial membranes of the PHA stimulated lymphocytes but it was still to a lesser extent than $\left[\mathrm{Au}(\mathrm{dppe})_{2}\right] \mathrm{Cl}$. MM6 had a more pronounced effect on the mitochondrial membranes of the cells tested than MM5. 


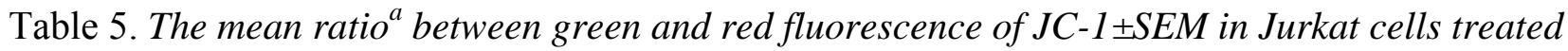
for $24 \mathrm{~h}$ with different concentrations of three selected drugs, treated and untreated controls.

\begin{tabular}{|l|l|l|}
\hline Experimental compound & Concentration $(\boldsymbol{\mu M})$ & Mean ratio \\
\hline$\left[\mathrm{Au}(\mathrm{dppe})_{2}\right] \mathrm{Cl}$, & 0.157 & $408.477 \pm 9.297 * * * \mathrm{~b}$ \\
\hline & 0.314 & $406.777 \pm 10.116^{* * *}$ \\
\hline MM5 & 0.261 & $476.092 \pm 12.460$ \\
\hline & 0.522 & $453.785 \pm 13.271$ \\
\hline MM6 & 0.369 & $468.677 \pm 10.839$ \\
\hline & 0.738 & $520.215 \pm 21.642$ \\
\hline Valinomycin & 0.1 & $422.262 \pm 11.476^{* * *}$ \\
\hline Valinomycin & 10 & $424.659 \pm 8.113^{* * *}$ \\
\hline Untreated control & 0 & $482.231 \pm 14.313$ \\
\hline
\end{tabular}

${ }^{*} p<0.01,{ }^{* *} p<0.001$ and ${ }^{* * *} p<0.0001$ compared to the untreated control.

${ }^{a}$ Mean of 13 independent experiments.

${ }^{\mathrm{b}}$ Significance was determined by the Student's $t$-test for paired values. 


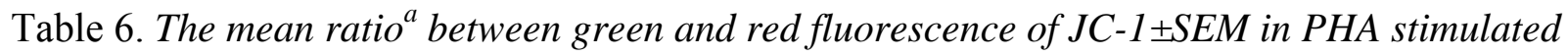
human lymphocytes treated for $24 \mathrm{~h}$ with different concentrations of 3 selected drugs, treated and untreated controls.

\begin{tabular}{|l|l|l|}
\hline Experimental compound & Concentration $(\boldsymbol{\mu M})$ & Mean ratio \\
\hline$\left[\mathrm{Au}(\mathrm{dppe})_{2}\right] \mathrm{Cl}$ & 0.254 & $447.450 \pm 14.579 * * * \mathrm{~b}$ \\
\hline & 0.508 & $415.150 \pm 15.685 * * *$ \\
\hline MM5 & 0.340 & $478.388 \pm 22.285^{* *}$ \\
\hline & 0.680 & $445.413 \pm 9.757 * *$ \\
\hline MM6 & 0.397 & $467.713 \pm 14.791 *$ \\
\hline & 0.794 & $441.213 \pm 15.658 * *$ \\
\hline Valinomycin & 0.1 & $396.500 \pm 10.244 * * *$ \\
\hline Valinomycin & 10 & $373.450 \pm 10.662 * * *$ \\
\hline Untreated control & 0 & $542.125 \pm 26.217$ \\
\hline
\end{tabular}

${ }^{*} p<0.01,{ }^{* *} p<0.001$ and ${ }^{* * *} p<0.0001$ compared to the untreated control.

${ }^{a}$ Mean of eight independent experiments.

${ }^{\mathrm{b}}$ Significance was determined by the Student's $t$-test for paired values.

\subsection{Apoptosis}

The apoptotic effect of $\left[\mathrm{Au}(\mathrm{dppe})_{2}\right] \mathrm{Cl}$, is shown in Table 7. Apoptotic effects of MM5 and MM6 are shown in Table 8. [Au(dppe $\left.)_{2}\right] \mathrm{Cl}$ induced apoptosis in Jurkat cells at both the concentrations that were used, with more effect at the higher concentration of $0.314 \mu \mathrm{M}$. MM5 at the concentration of $0.261 \mu \mathrm{M}$ had no effect on the Jurkat cells during the 48 hour incubation period. The higher concentration did have an effect on the cells, but it seems that necrosis was more indicative than apoptosis. MM6 had very clear apoptotic effects at both the concentrations tested, more so with the higher concentration (Table 9). 
Table 7. The mean percentage $e^{a}$ of Jurkat cells still viable, in early apoptosis, late apoptosis and necrosis $\pm S E M$, treated with different concentrations of [Au(dppe $\left.)_{2}\right] \mathrm{Cl}$ for 18, 24 and $48 \mathrm{~h}$.

\begin{tabular}{|c|c|c|c|}
\hline & Control & {$\left[\mathrm{Au}(\mathrm{dppe})_{2}\right] \mathrm{Cl} 0.157(\mu \mathrm{M})$} & {$\left[\mathrm{Au}(\mathrm{dppe})_{2}\right] \mathrm{Cl} 0.314(\mu \mathrm{M})$} \\
\hline$\%$ Viable cells & $93.18 \pm 1.06$ & $91.78 \pm 1.01$ & $91.14 \pm 1.18$ \\
\hline \multicolumn{4}{|l|}{$18 \mathrm{~h}$} \\
\hline$\%$ Early apoptosis & $1.91 \pm 0.43$ & $2.05 \pm 0.42$ & $1.74 \pm 0.25$ \\
\hline$\%$ Late apoptosis & $2.05 \pm 0.27$ & $3.85^{* \mathrm{~b}} \pm 0.97$ & $4.23 \pm 1.25$ \\
\hline$\%$ Necrosis & $1.22 \pm 0.36$ & $1.45 * \pm 0.34$ & $1.70 * \pm 0.31$ \\
\hline$\%$ Viable cells & $93.18 \pm 1.13$ & $90.90 * \pm 1.36$ & $90.52 * * \pm 1.52$ \\
\hline \multicolumn{4}{|l|}{$24 \mathrm{~h}$} \\
\hline$\%$ Early apoptosis & $2.25 \pm 0.55$ & $2.48 \pm 0.56$ & $2.33 \pm 0.59$ \\
\hline \% Late apoptosis & $2.33 \pm 0.23$ & $3.80 * \pm 0.68$ & $4.37 \pm 0.75$ \\
\hline$\%$ Necrosis & $1.29 \pm 0.33$ & $1.91 \pm 0.43$ & $2.01 * \pm 0.45$ \\
\hline$\%$ Viable cells & $93.81 \pm 0.45$ & $69.38 \pm 11.95$ & $34.49 * \pm 16.43$ \\
\hline \multicolumn{4}{|l|}{$48 \mathrm{~h}$} \\
\hline$\%$ Early apoptosis & $2.69 \pm 0.48$ & $4.30 * \pm 1.10$ & $2.24 \pm 0.46$ \\
\hline$\%$ Late apoptosis & $1.48 \pm 0.08$ & $12.7 \pm 4.91$ & $15.61 * \pm 4.16$ \\
\hline$\%$ Necrosis & $0.99 \pm 0.11$ & $12.53 \pm 6.38$ & $68.06^{*} \pm 2.51$ \\
\hline
\end{tabular}

${ }^{*} p<0.01,{ }^{* *} p<0.001$ and ${ }^{* * *} p<0.0001$ compared to the untreated control.

${ }^{a}$ Mean of seven independent experiments.

${ }^{\mathrm{b}}$ Significance was determined by the Student's $t$-test for paired values. 
Table 8. The mean percentage ${ }^{a}$ of Jurkat cells still viable, in early apoptosis, late apoptosis and necrosis $\pm S E M$, treated with different concentrations of MM5 and MM6 for 18, 24 and 48 h.

\begin{tabular}{|c|c|c|c|c|}
\hline & \multicolumn{2}{|l|}{ MM5 } & \multicolumn{2}{|l|}{ MM6 } \\
\hline & $0.261(\mu \mathrm{M})$ & $0.522(\mu \mathrm{M})$ & $0.369(\mu \mathrm{M})$ & $0.738(\mu \mathrm{M})$ \\
\hline$\%$ Viable cells & $91.88^{* \mathrm{~b}} \pm 1.38$ & $87.52 \pm 3.28$ & $79.53 * \pm 2.86$ & $52.13 * * \pm 6.47$ \\
\hline \multicolumn{5}{|l|}{$18 \mathrm{~h}$} \\
\hline$\%$ Early apoptosis & $2.04 \pm 0.40$ & $4.05 \pm 1.30$ & $4.65 \pm 1.35$ & $3.85 \pm 0.71$ \\
\hline$\%$ Late apoptosis & $3.23 * \pm 0.51$ & $3.93 \pm 0.97$ & $7.52 * * \pm 1.03$ & $16.72 * * \pm 3.94$ \\
\hline$\%$ Necrosis & $2.17 \pm 0.76$ & $2.38 * \pm 0.59$ & $5.46 * * \pm 0.99$ & $21.79 * * \pm 3.48$ \\
\hline$\%$ Viable cells & $90.46^{*} \pm 2.16$ & $80.64 \pm 8.83$ & $77.17 * * \pm 3.37$ & $34.97 * * * \pm 8.12$ \\
\hline \multicolumn{5}{|l|}{$24 \mathrm{~h}$} \\
\hline$\%$ Early apoptosis & $3.03 \pm 0.51$ & $2.60 \pm 0.23$ & $2.28 \pm 0.21$ & $3.80 \pm 1.24$ \\
\hline$\%$ Late apoptosis & $3.17 * \pm 0.87$ & $7.49 \pm 3.27$ & $11.82 * * \pm 1.77$ & $23.98 * * \pm 4.84$ \\
\hline$\%$ Necrosis & $2.33 \pm 0.93$ & $8.04 \pm 5.46$ & $7.73 * * \pm 1.84$ & $36.41 * *_{ \pm} 9.30$ \\
\hline$\%$ Viable cells & $90.20 * * \pm 1.52$ & $75.28 \pm 13.74$ & $70.69 * * \pm 2.24$ & $11.05 * * * \pm 2.34$ \\
\hline \multicolumn{5}{|l|}{$48 \mathrm{~h}$} \\
\hline$\%$ Early apoptosis & $3.81 \pm 0.77$ & $3.20 * \pm 0.88$ & $3.15 \pm 0.62$ & $1.10 * * \pm 0.29$ \\
\hline \% Late apoptosis & $2.37 * \pm 0.19$ & $5.95 \pm 2.02$ & $14.92 * \pm 4.12$ & $24.36 * * * \pm 3.85$ \\
\hline$\%$ Necrosis & $2.47 \pm 1.01$ & $15.37 \pm 12.5$ & $16.44 * * \pm 3.14$ & $63.83 * * * \pm 5.42$ \\
\hline
\end{tabular}

${ }^{*} p<0.01,{ }^{* *} p<0.001$ and ${ }^{* * *} p<0.0001$ compared to the untreated control.

${ }^{\mathrm{a}}$ Mean of 7 independent experiments.

${ }^{\mathrm{b}}$ Significance was determined by the Student's $t$-test for paired values. 
Table 9. The mean percentage $e^{a}$ of uptake of ${ }^{198} \mathrm{Au}$-labeled [Au(dppe $\left.)_{2}\right] \mathrm{Cl}$, MM5 and MM6 \pm SEM in A2780 and A2780 cis cells after treatment with different concentrations for $1 \mathrm{~h}$.

\begin{tabular}{|l|l|l|l|}
\hline Drug & Concentration $(\mathbf{m M})$ & \% Uptake A2780 \pm SEM & \% Uptake A2780 cis \pm SEM \\
\hline$\left[\mathrm{Au}(\mathrm{dppe})_{2}\right] \mathrm{Cl}$ & 1 & $45.74 \pm 4.4$ & $13.92 \pm 0.93$ \\
\hline$\left[\mathrm{Au}(\mathrm{dppe})_{2}\right] \mathrm{Cl}$ & 5 & $32.59 \pm 3.44$ & $23.66 \pm 2.55$ \\
\hline$\left[\mathrm{Au}(\mathrm{dppe})_{2}\right] \mathrm{Cl}$ & 10 & $33.95 \pm 2.64$ & $26.25 \pm 1.97$ \\
\hline MM5 & 1 & $5.04 \pm 0.73$ & $2.99 \pm 0.38$ \\
\hline MM5 & 5 & $4.14 \pm 0.38$ & $1.40 \pm 0.11$ \\
\hline MM5 & 10 & $3.77 \pm 0.26$ & $1.50 \pm 0.14$ \\
\hline MM6 & 1 & $3.01 \pm 0.33$ & $2.76 \pm 0.45$ \\
\hline MM6 & 5 & $2.12 \pm 0.23$ & $0.80 \pm 0.13$ \\
\hline MM6 & 10 & $1.66 \pm 0.27$ & $0.94 \pm 0.03$ \\
\hline
\end{tabular}

${ }^{\mathrm{a}}$ Each value represents the mean of six independent experiments.

\subsection{In vitro drug uptake of radiolabeled Au-compounds}

$\left[\mathrm{Au}(\mathrm{dppe})_{2}\right] \mathrm{Cl}$ which is the most lipophilic had the best uptake by the A2780 (cisplatin sensitive) cells at the lowest concentration of $1 \mathrm{mM}$. Drug uptake of $\left[\mathrm{Au}(\mathrm{dppe})_{2}\right] \mathrm{Cl}$ by the $\mathrm{A} 2780$ cis (cisplatin resistant) cells was considerably lower. MM5 and MM6 which are hydrophilic were not taken up well by either of the two cell lines tested.

\subsection{In vivo rodent studies}

Based on the in vitro results of MM5 and MM6 it was decided to do an animal study to determine the biodistribution of these compounds. ${ }^{198} \mathrm{Au}$ labeled $\left[\mathrm{Au}(\mathrm{dppe})_{2}\right] \mathrm{Cl}$, MM5 and MM6 was used in rats. The biodistribution showed predominantly high reticulo-endothelial uptake for all the experimental compounds. The solubility of these compounds was very low. The lungs showed high uptake of $\left[\mathrm{Au}(\mathrm{dppe})_{2}\right] \mathrm{Cl}$ which could be the result of colloid forming which is a result of the low solubility. Higher levels of distribution was found for $\left[\mathrm{Au}(\mathrm{dppe})_{2}\right] \mathrm{Cl}$ than for MM5 and MM6. These results confirm the results obtained in the octanol/water partition coefficient experiments and the radiolabeled drug uptake experiments. MM5 and MM6 are more hydrophilic and according to the results obtained in these experiments, they have limited biodistribution in comparison to the more lipophilic $\left[\mathrm{Au}(\mathrm{dppe})_{2}\right] \mathrm{Cl}$. This might imply a more selective tumour uptake (Fig. 2). 


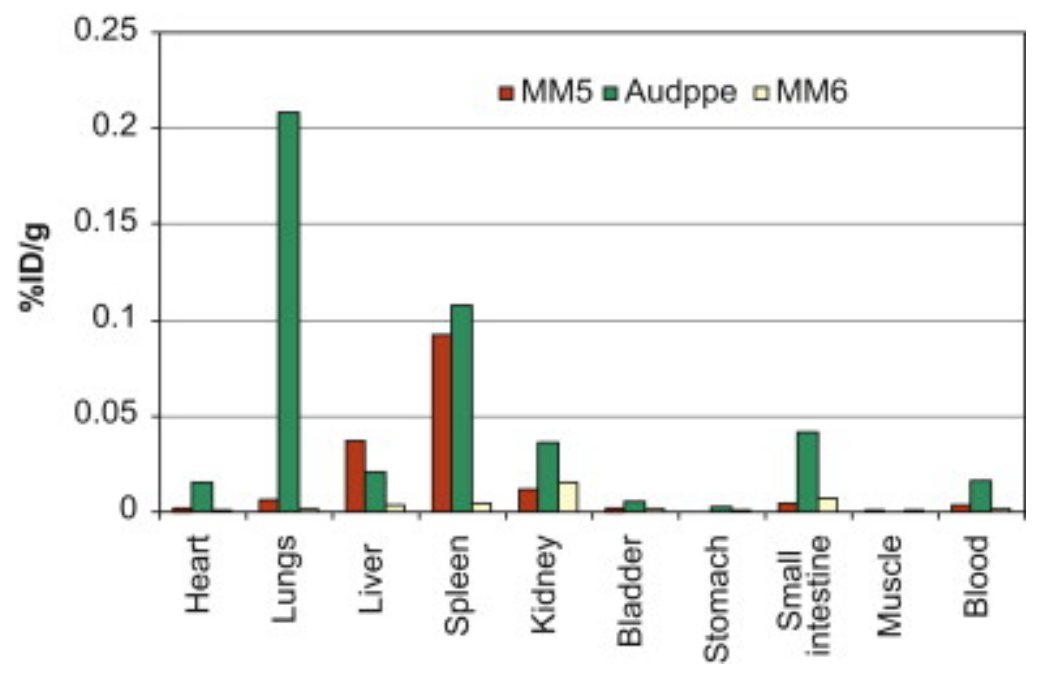

Fig. 2. Bio distribution of ${ }^{198} \mathrm{Au}$-labeled compounds in rats.

\section{Conclusion}

Results obtained from these experiments showed that the uptake of these experimental compounds was dependent on their octanol/water partition coefficient. However; the inhibition of cell growth did not correlate with the uptake of these compounds by the cells that were tested.

In terms of the total uptake it was found that the compounds that were less lipophilic (MM5, MM6) were taken up less efficiently in cells than those that are more lipophilic. Therefore hydrophilic drugs are expected to have a limited biodistribution compared to lipophilic drugs. This might imply a more selective tumour uptake.

\section{Acknowledgement}

The authors thank Necsa for permission to publish this work.

\section{References}

Anderson et al., 1993 R. Anderson, M.J. Smit and C.E.J. van Rensburg, Lysophospholipid-mediated inhibition of $\mathrm{Na}, \mathrm{K}$ - adenosine triphosphatase is a possible mechanism of immunorepressive activity of cyclosporin A, Mol. Pharmacol. 44 (1993), pp. 605-619.

Berners-Price et al., 1986 S.J. Berners-Price, C.K. Mirabelli, R.K. Johnson, M.R. Mattern, F.L. McCabe, L.F. Faucette, C.-M. Sung, S.-M. Mong, P.J. Sadler and S.T. Crooke, In vivo anti-tumor 
activity and in vitro cytotoxic properties of Bis [1, 2-bis(diphenyl phosphino)ethane]gold(I)chloride, Cancer Res. 46 (1986), pp. 5486-5493.

Berners-Price et al., 1999 S.J. Berners-Price, R.J. Bowen, P. Galettis, P.C. Healy and M.J. McKeage, Structural and solution of gold(I) and silver(I) complexes of bidentate pyridyl phosphines: selective anti-tumor agents, Coord. Chem. Rev. 186 (1999), pp. 823-836.

Berners-Price and Sadler, 1986 S.J. Berners-Price and P.J. Sadler, Gold(I) complexes with bidentate tertiary phosphine ligands: formation of annular vs. tetrahedral chelated complexes, Inorg. Chem. 25 (1986), pp. 3822-3827.

Bowen, 1999 Bowen, R.J., 1999. Hydrophilic bidentate phosphines and their group 11 complexes: potential anti-tumour agents. Ph.D. Thesis, Griffith University, Australia, 112.

Caruso et al., 2007 F. Caruso, R.V. Villa, M. Rossi, C. Pettinari, F. Paduano, M. Pennati, M.G. Daidone and N. Zaffaroni, Mitochondria are primary targets in apoptosis induced by the mixed phosphine gold species chlorotriphenylphosphine-1,3-bis(diphenylphosphino)propanegold(I) in melanoma cell lines, Biochem. Pharmacol. 73 (2007), pp. 773-781.

Cossarizza et al., 1993 A. Cossarizza, M. Baccarani-Contri, G. Kalashnikova and C. Franceschi, A new method for the cytofluorimetric analysis of mitochondrial membrane potential using the Jaggregate forming lipophilic cation 5,5',6,6'tetrachloro-1,1',3,3'-tetraethylbenzimidazolcarbocyanine iodide (JC-1), Biochem. Biophys. Res. Commun. 197 (1) (1993), pp. 40-45.

Debatin et al., 2002 K.M. Debatin, D. Poncet and G. Kroemer, Chemotherapy: targeting the mitochondrial cell death pathway, Oncogene 12 (57) (2002), pp. 8786-8803.

Freshney, 2000 R.I. Freshney, Culture of Animal Cells: A Manual of Basic Technique (fourth ed), Wiley-Liss Publishers, New York (2000).

Frühauf et al., 2004 N.R. Frühauf, K.J. Oldhafer, M. Höltje, G.M. Kaiser, J.H. Frühauf, G.A. Stavrou, A. Bader and C.E. Broelsch, A bio artificial liver support system using primary hepatocytes: a preclinical study in a new porcine hepatectomy model, Surgery 136 (2004), pp. 47-56. 
Hoke et al., 1988 G.D. Hoke, G.F. Rush, G.E. Bossard, J.V. McArdle, B.D. Jensen and C.K. Mirabelli, Mechanism of alterations in isolated rat liver mitochondrial function induced by gold complexes of bidentate phosphines, J. Biol. Chem. 263 (23) (1988), pp. 11203-11210.

Hoke et al., 1991 G.D. Hoke, F.L. McCabe, L.F. Faucette, J. O’Leary Bartus, C.-M. Sung, B.D. Jensen, R. Heys, G.F. Rush, D.W. Alberts, R.K. Johnson and C.K. Mirabelli, In vivo development and in vitro characterization of a subclone of Murine P388 Leukemia resistant to bis(diphenylphosphine)ethane, Mol. Pharmacol. 39 (1) (1991), pp. 90-97.

Mahepal et al., 2008 Mahepal, S., Bowen, R., Mamo, M.A., Layh, M., Jansen van Rensburg, C.E., 2008. The in vitro antitumour activity of novel, mitochondrial-interactive, gold-based lipophilic cations. Met. Based Drugs. 2008, doi:10.1155/2008/864653 (Article ID 864653, 5 pages).

Michie et al., 2003 J. Michie, J. Akudugu, A. Binder, C.E.J. Van Rensburg and L. Böhm, Flow cytometric evaluation of apoptosis and cell viability as a criterion of anti-tumour drug toxicity, Cancer Res. 56 (2003), pp. 544-550.

Modica-Napolitano and Aprille, 2001 J.S. Modica-Napolitano and J.R. Aprille, Delocalized lipophilic cations selectively target the mitochondria of carcinoma cells, Adv. Drug Delivery Rev. 49 (1-2) (2001), pp. 63-70.

Nieuwoudt et al., 2005 M.J. Nieuwoudt, E. Kreft, B. Olivier, S. Malfeld, J. Vosloo, F. Stegman, R. Kunneke, A.J. Van Wyk and S.W. Van der Merwe, A large-scale automated method for hepatocyte isolation: effects on proliferation in culture, Cell Transpl. 14 (5) (2005), pp. 291-299.

Smith et al., 1989 P.F. Smith, G.D. Hoke, D.W. Alberts, P.J. Bugelski, S. Lupo, C.K. Mirabelli and G.F. Rush, Mechanism of toxicity of an experimental bidentate phosphine gold complexed antineoplastic agent in isolated rat hepatocytes, Pharmacol. Exp. Ther. 249 (3) (1989), pp. 944-950.

Tsuruo et al., 1982 T. Tsuruo, H. Iida, S. Tsukagoshi and Y. Sakurai, Increased accumulation of Vincristine and Adriamycin in drug-resistant P388 tumor cells following incubation with calcium antagonists and calmodulin inhibitors, Cancer Res. 42 (1982), pp. 4730-4733. 
Tuschl and Schwab, 2004 H. Tuschl and C.E. Schwab, Flow cytometric methods used as screening tests for basal toxicity of chemicals, Toxicol. in vitro 18 (2004), pp. 483-491. 